\title{
Executive remuneration: industry and job family effects
}

\section{Frans Maloa}

To cite this article: Maloa, F. (2017). Executive Remuneration: Industry and Job Family Effects. International Journal of Public Administration, 40(3), 284-294.

To link to this article: $h t t p: / / d x . d o i . o r g / 10.1080 / 01900692.2015 .1107739$

\begin{abstract}
This research explores the distribution of executive remuneration based on the type of industry and job family in South African state-owned enterprises. A regression analysis of secondary data collected on 222 executives was conducted. The overall results based on pairwise comparison suggest that the distribution of executive remuneration across various categories of industry was the same except between forestry - defence, forestry - telecommunications, defence - telecommunications, and energy - development funding. However, the results also indicated that there was no difference in the distribution of remuneration across various categories of job families in South African state-owned enterprises.
\end{abstract}

Key words: executive remuneration, industry, job family, state-owned enterprises, 


\section{Introduction}

A basic goal for every employer is to determine how salaries compare with those of employers that are seen as competitors for talent and to adjust the pay programme periodically to maintain the planned alignment (Risher, 2012). However, it would be difficult to decide on the magnitude of pay differentials for different occupations without addressing the design, sector and industry, job function and external equity against which such remuneration could be benchmarked (Bizjak, Lemmon \& Naveen, 2008; Bizjak, Lemmon, \& Nguyen, 2011; Chatterji, Mumford \& Smith, 2011; Ghose, 2011; Greckhammer, 2011; Perkins \& White, 2011).

The design of compensation schemes is a key factor that affects behaviour and awareness of acting in accordance with the overriding aims of the public authority. Scholars in public administration, political science and economics have written that the distinctive characteristics of public organisations and the people in them have significant implications for public administration and for governance (Bullock, Stritch \& Rianey, 2015). Whenever astronomically high pay of chief executive officers (CEOs) was highlighted in the media, the obvious question was whether executives were justified in accumulating massive wealth through remuneration (Sarkar, 2013).

Recent developments have shifted away from treating executive remuneration as an internal consideration in which only internal equity and job evaluation in an organisation are used to determine remuneration (Mcgovern \& Williams, 2012). The rise of external influencers, such as the industry and the market in which an organisation belongs, seems to contribute to the main determinants of executive remuneration.

Similarly, Perkins and White (2011) argue that commentary in the academic and related literature attempting to theorise executive pay and the contingencies against which it is determined reveals a range of views. The recent literature of finance (Ang, Nagel \& Yang 2013; 
Bizjak, Lemmon \& Naveen, 2008) shows that executive pay is benchmarked against industry peers of comparable size. Moreover, Faulkender and Yang (2010) and Bizjak, Lemmon, and Nguyen (2011) show that in addition to industry and size considerations, organisations select peer organisations that pay their chief executive (CEOs) more generously to justify CEO pay. While much has been mentioned about the employment effects of the privatisation of South African state-owned enterprises (SOEs) the debate has largely overlooked the impact of these events on wage levels (Hatting, Hodges \& Rospabe, 2003). To understand the nature of South African SOEs and their implication for executive remuneration, a discussion of the definition of such institutions may be necessary.

SOEs are known by many names - government corporations, government business enterprises, government-linked companies, parastatals, public enterprises, public sector units or enterprises and so on (PwC, 2015). South African SOEs have not escaped scrutiny with regard to their real identity. According to the policy discussion paper on South African SOEs and Development Finance Institutions (DFIs) (2012), the area of state-owned entities is awash with acronyms and abbreviations, which often leads to definitional confusion. According to the presidential review committee on South African SOEs released in 2013, notable observations and findings are that South Africa has no common agenda for and understanding of South African SOEs.

In addition to the absence of a consolidated national repository for all SOEs, there is confusion about the categorisation of South African SOEs in terms of whether they should be classified as private or public sector organisations. While much has been mentioned about the employment effects of the privatisation of South African SOEs, the debate has largely overlooked the impact of these events on the wage levels of those workers who retained their jobs during the restructuring process (Hatting, Hodges \& Rospabe, 2003). The understanding then was that a South African SOE would shift to become a partially private firm that would 
operate in a highly regulated industry structure with limited competition. Over time South African SOEs were expected to earn abnormal profits and unionised labour was also going to share in some of those profits (Hatting, Hodges \& Rospabe, 2003).

However, according to an ANC policy discussion paper on South African SOEs and DFIs published in 2012, South African SOEs were not created to maximise profits or incur losses; rather their existence was for the purpose of driving the development agenda. The dual mandate of South African SOEs was to achieve a balance between the required level of self-funding and undertaking developmental projects that the private sector would ordinarily not do. These policies were to ensure that the South African SOEs, tasked with costly development mandates, were strategically positioned to generate sufficient revenue to cover the costs associated with fulfilling their respective, but interrelated, mandates. What seems to be a challenge though is the dual character of South African SOEs as having attributes of both the public and the private sector.

However, it seems that the challenge with defining the sector according to which South African SOEs can be categorised is part of a larger confusion between public and private sector organisations. As explained by Bullock, Stritch and Rainey (2015), experts and observers (e.g. Bozeman, 1987; Musolf \& Seidman, 1980) have repeatedly emphasised the "blurring" of the public, private, and non-profit sectors. These experts argue that the sectors are mingled and overlapping, making simple distinctions impossible. The contexts of organisations, moreover, can vary widely within and across nations (Houston 2011; Kjeldsen \& Anderson 2013; O'Toole \& Meier 2015).

However, the presidential Review Committee (2013) asserts that the name 'state-owned enterprise' must be used to refer to incorporated and non-incorporated commercial entities, and the name 'public entities' must be used to refer to all non-commercial entities. In addition, an 
SOE is regarded as a legal entity created by government to undertake commercial activities on behalf of the owner, government. Their legal status could vary, from being part of government to being public companies with the state as a shareholder.

While the varying forms of SOEs may provide governments with flexibility, these multiple forms may also serve to complicate ownership policy, make them less transparent and insulate SOEs from the legal framework applicable to other companies, including competition laws, bankruptcy provisions or securities laws (PwC, 2015). There are also challenges with regard to balancing the trade-offs between commercial and non-commercial objectives of South African SOEs.

The multiple forms of SOEs seem to be the cause for debate on maladministration and corruption in the management of executive remuneration in SOEs. According to Rodriquez, Uhlenbruck and Eden (2005, p.383) the most general definition of corruption is "the abuse of public power for private benefit". Transparency International (2004) has defined corruption as the abuse of entrusted power for private gain. Similarly, Jain (2001) defines corruption as an act in which the power of public office is used for personal gain in a manner that contravenes the rules of the game. These definitions explicitly refer to the private gain of all agents involved in the corrupt act (Sherman, 1980, p. 480).

An element of corruption as defined in this study seems to be present to some extent in the context of South African SOEs. For example, according to the Transparency International report of 2014, South Africa ranks 67th with a score of 44 in a sample of 175 countries in terms of perceived corruption. This means that South Africa is perceived to be a fairly corrupt society. Some degree of corruption is further substantiated by events and developments in the determination of executive remuneration in SOEs, as discussed below. 


\section{Events and developments at an electricity supplier state-owned enterprise}

In 2007, giving a written reply to a parliamentary question from Freedom Front Plus parliamentary leader Pieter Groenewald, the Honourable Hogan, then Minister of Public Enterprises, in defence of the remuneration package of the electricity supplier SOE's CEO, mentioned that the CEO's remuneration was similar to the percentage increase awarded to all top management employees during the October 2007 annual increase period. However, in April 2008 the CEO got another $15.31 \%$ increase - the median of the market, which according to the Minister took the CEO to R4 750000 on the anniversary of his appointment. Then again in October, when the company paid everyone annual increases, the CEO was paid another $8.84 \%$, taking his remuneration to R5 170000 (Fin.24.com, Nov 2009).

In 2009, the board of the electricity power supplier rewarded the efforts of the CEO to keep South Africa's lights on with a $26.7 \%$ salary increase, considerably more than the $10.5 \%$ given to the rest of the power utility's workforce. The CEO in his defence mentioned that he did not bargain for his package but that the board made an assessment and decided what to award. The CEO asserted that the board had arrived at the decision after assessing his performance (Sowetan, 2009).

The Minister of Public Enterprises mentioned that pay increases were awarded in terms of the SOE's remuneration policy to reward executives "at the median of the market" (Fin24.com, July 2010). The statement by the Minister with reference to the median of the market seems to suggest that executive compensation within the electricity power supplier SOE was determined by external equity, which involves comparing the enterprise's executive remuneration to that of other similar organisations in the market. However, from the statements made by the Minister, it was not clear to which market the Minister was referring against which it was 
relevant to benchmark the salary of the CEO, since it concerned the only major supplier of electricity in South Africa.

Furthermore, the Minister explained that subsequent to his appointment, the power supplier had changed its remuneration approach for managers from a "salary plus benefits" to a total guaranteed package (TGP) basis. Benefits such as a pension fund and medical aid were then structured within the TGP. "There are no fixed bonuses," she said. "Bonuses are based on an individual's performance over 12 months." But bizarrely, she listed the first bonus the CEO received as a short-term incentive bonus of R1 103 000. It was allocated in March 2007 - a full month or more before he was actually officially appointed, although he was made CEO designate in February (Fin24.com, July 2010).

In general, SOE's executives were awarded an average salary hike of $25 \%$ for the 2010 financial year. That was more than five times the prevailing inflation rate of $4.6 \%$ at that time (Fin24.com, July 2010).

\section{Events and developments at an airline state-owned enterprise}

A KPMG report (2010) states that in 2007, at the time when a South African airline enterprise was undertaking a substantial exercise of restricting its business, a retention bonus scheme was approved, which was intended to incentivise key and critical employees to remain in the employ of the airline. A maximum financial cost for the scheme was approved and the implementation of the scheme was delegated to the CEO and members of his then executive support team.

However, according to the KPMG report, investigations revealed that retention bonus contracts were concluded, by or with the approval of the CEO, for a total amount that in aggregate exceeded the maximum financial limit that had been imposed for the scheme in an amount of 
over R27 million. This excess was not authorised by the board and it was beyond the powers of the CEO to expend such monies (KPMG report, 2010). The events at the airline seem to indicate that there was no clear-cut guideline on how incentives could be allocated and managed within the airline. The question remains, what informed the allocation of such incentives?

\section{Events and developments at a transport logistics utility state-owned enterprise}

According to the Sowetan (2012), the uncertainty that accompanied the clear administration and management of executive remuneration saw the Minister of Public Enterprises putting a stop to increases in executive pay in all South African SOEs until an effective and efficient guideline was in place. The Minister of Public Enterprises was particularly incensed by two instances of "excessive executive pay" at one of these parastatals, otherwise known as stateowned entities in politically correct terms (Sowetan, 16 March 2012).

The first was a report that a non-executive director at the transport logistics utility enterprise had recently earned more than R138 000 for attending only three of five meetings, or R34 500 a sitting. The second related to the payment of more than R10 million in incentives and bonuses to the CEO for the period he was on suspension while allegations of graft were being investigated against him (Sowetan, 16 March 2012). The Minister's frustration demonstrated that there was a need for an informed guideline on executive compensation in the context of South African SOEs.

However, in South Africa, the Companies Act of 2008 and the King III provide some guidance on corporate governance but do not pronounce explicitly on the governance of SOEs and their executive remuneration in particular. It can only be assumed from the legal provisions that SOEs as companies are covered. Besides, there seem to be gaps with regard to remuneration even in the context of the private sector. For example, referring to King III compliance, 
Seegers, a partner at PwC, said a major focus area for remuneration committees should be to re-evaluate the appropriateness of performance conditions and targets in respect of short- and long-term incentive plans. "They must also revisit levels of disclosure, and ensure they are prepared for greater shareholder consultation and AGM discussions." (Fin24.com, August 2010). However, the overall implication is that policy initiatives in this field need to integrate SOEs in a more specific way that would be transparent for the management of executive remuneration in such institutions.

Prior to this research, no empirically validated and reliable study on the governance of executive remuneration existed in the context of South African SOEs. However, a remuneration guideline for South African SOEs was established in 2007, following proposals by the DPE to address issues concerning executive pay.

In 2011 a new model, which would serve as an improvement on the 2007 model, was established. The Minister of Public Enterprises told Parliament's standing committee on public accounts in March 2012 that the freezing of executives' pay increases at all state-owned entities under his department would be in place until a proper remuneration policy had been put in place. The Minister stated that the remuneration of executives was generally quite high and "did not contribute to bridging the inequality gaps between the highest paid and lowest paid" (Sowetan, 16 March 2012).

In 2012, the deputy director-general of the DPE presented a progress report on the work that had been done by the panel tasked with reviewing executives' pay. The deputy director-general mentioned that the panel had taken a provisional report containing a set of recommendations on the restructuring of executives' pay and incentives to cabinet (Sowetan, 16 March 2012). Among its recommendations was remodelling of short-term incentives, such as once-off bonuses, to link them to performance and abolishing long-term incentives for executive 
directors, such as retention fees. In addition, it was recommended that the size and the asset value of each enterprise should not be taken into consideration when setting executive compensation. If the recommendations of the panel were accepted, it would mean the size and asset value of SOEs would not be accepted as a reason for paying executives at larger South African SOEs more than those at smaller South African SOEs. The recommendations made by the review panel seemed to suggest that there was no easy solution to challenges experienced in executive remuneration in South African SOEs.

The DPE was also concerned about South African SOEs benchmarking themselves against JSE-listed companies in terms of executive remuneration when their mandates were different from those of such companies (Sowetan, 25 April 2012). Oberholzer and Theunissen (2012) contend that an acceptable benchmarking model is needed to indicate an acceptable level of remuneration and to indicate whether a particular executive is being over-or underpaid in the context of business-specific elements.

However, this paper argues that comprehensive and reliable data on executive remuneration based on the type of industry are the benchmark SOEs need to support their salary budget increase recommendations. This is so since according to Ghose (2011), regardless of levels, pay benchmarking is best conducted within industry definitions, as more often than not executives progress in their career development to senior positions in the same industry. Consequently, it would seem that better pay benchmarking of executive remuneration among SOEs can be achieved by comparing how similar institutions measure up to others in similar industries with pay increase budgets so that they are able to remain competitive in terms of attracting and retaining the best talent. The utilisation of industry as a benchmark can assist in shedding some light on the matter and curbing the uncertainty about executive remuneration in the context of SOEs. Therefore, the preceding argument leads to the null hypothesis to be tested in this article, namely: 
$H_{0}(1)$ : The distribution of executive remuneration is the same across various categories of industry in South African SOEs.

Furthermore, executives hold different types of jobs and are employed in different occupations (Datta Gupta, Poulsen \& Villeval, 2013). The importance of a job function in an organisation in terms of remuneration can be measured by its comparison to other similar jobs in the job family. Job families are usually arranged by functional groups or work categories such as administration or customer services, finance, information technology (IT) or personnel, or by occupation, for example IT specialists or scientists (Armstrong \& Brown, 2001). Armstrong and Brown point out that this approach of using job families in remuneration is likely to figure where management is of the opinion that different occupations require different reward and/or career development practices. Thus, comparison of job functions that belong to a specific job family can spell out the distribution of executive remuneration. Its comparison is intended to achieve external equity.

External equity refers to the fairness of the pay for a specific job in an organisation in comparison to the pay for similar jobs in other organisations in the relevant industry (Martocchio, 2010). "First, to attract and retain a qualified workforce, the firm must identify what the prevailing wage is for each of its jobs. Second and related to the first point, the going rate in the labour market becomes the key factor for ascertaining job value or worth and hence, external equity is defined as the extent to which the firm's pay rate for a given job matches the prevailing rate for that job in the external labour market" (Gomez-Mejia et al., 2010: 8). Therefore, the preceding discussion leads to the null hypothesis to be tested in this research paper, namely:

$H_{0}$ (2): The distribution of executive remuneration is the same across various categories of job families in South African SOEs. 
The goal of this study was therefore to establish if there was any difference in the distribution of fixed remuneration across various categories of industry and job families in South African SOEs.

This paper contributes to the literature. First, it addresses recent calls in the literature for research into the determinants of executive remuneration, especially in the South African context (Crotty \& Bonorchis, 2006; Lorsch \& Khurana, 2010; Maloa \& Rajah, 2012; PwC, 2010; Oberholzer \& Theunissen, 2013; Theunissen, 2010; Van Zyl, 2010). Second, the study provides evidence of the role of industry and job family in executive remuneration. Third, by collecting data from a large sample of South African SOEs, this study provides a broad picture of current practices across a group of organisations.

In what follows, the second section places the discussion in the context of the theoretical perspective through which the effect of industry and job family on the distribution of remuneration could be explained. The methodology followed in this research is discussed in the third section and the findings are presented in the fourth section, followed by the discussion and conclusion.

\section{Contingency theory}

The contingency theory calls for attention to the environmental influences that may affect executive remuneration (Robbins \& Judge, 2011; Sun, Zhao \& Yang, 2010). Contingency theory suggests that how executives are compensated is a result of how the organisation would like to compare with other similar organisations in the industry. This would include consideration of the enterprise industry competition situation, the nature of the industry, industry prospects and the tendency of the national legal system of the industry, among other elements. 
Trevor (2011, p. 42) contends that if contingency theory predictions hold true, collectively speaking, the effects of the industry (as an element of the environment) might be viewed as a contextually independent variable upon which firms' pay practices, as dependent variables, are contingent. If conformity of pay practices is observed in the sample of firms - both at industry level and firm level - the standard explanation of the normative influence of the 'industry effect' is both established and powerful. It is the markets and not managers that choose the prevailing strategies in a particular environment (Whittington, 1997). This clearly has a bearing on the pay trends observed in industry-level findings.

\section{Methodology and research design}

This was an exploratory research study and empirical research was conducted to gather quantitative data. In this study, the various categories of industry (see table 1) and job family (see table 4) as elements of executive remuneration in South African SOEs were explored, as well as their significance in predicting the distribution of executive remuneration in such entities.

\section{Research approach}

Both descriptive and exploratory research approaches were adopted for the study. The emphasis was on the quantification of variables and statistical controls. The literature review process was utilised as a point of departure to enable statistical analysis of the collected data.

\section{Sample}

For the purpose of this research project, the target population consisted of 21 SOEs under Schedule 2 organisations as defined in the Public Finance Management Act of 1999 (PFMA). Purposive sampling was conducted of executives that fall under the top management team as arranged according to Paterson grading E - lower to F - upper (including CEOs, directors and 
senior managers). On average, each enterprise had 10 executives. The total population size investigated was 222 executives. The 21 different SOEs were categorised into seven different industries, namely transportation/freight logistics (9.0\%), defence (6.3\%), energy (12.2\%), forestry (5.4\%), telecommunications (32.9\%), development funding (18.0\%) and aviation/aerospace $(16.2 \%)$.

The job family composition of the sample consisted of administration (25.8\%), followed by operations (21.3\%), human resources (12.2\%), finance, legal and risk (10\%) and strategy, sales and marketing (5.9\%). The least represented categories of job family were information technology (3.6\%), followed by strategy and finance (2.7\%) and strategy and administration $(2.3 \%)$

\section{Data collection}

The empirical data collected consisted of a salary corpus that contained information about the remuneration information of the executives. Data items investigated within the salary data corpus consisted of the current basic salary of all executives under study.

\section{Data processing}

The corpus of salary data of all the organisations under study was transferred onto an Excel spread sheet. After the data had been captured and edited, the Excel data were then imported into SPSS, Version 20.0 (a statistical programme for the social sciences) for statistical analysis. 


\section{Data analysis}

Quantitative analysis was carried out, with salary data of 222 participant executives. The salary data were compared based on various categories of job family and industry within which each executive and organisation operated. SPSS was used to perform statistical analysis. Data were summarised using descriptive statistics (such as mean, standard deviation and range), frequency distribution (percentages), correlation coefficients, and analysis of variance (ANOVA). Descriptive statistics were also calculated to describe variables numerically.

In analysing the relationships among the elements of executive remuneration, the productmoment correlation (r) was utilised. The researcher decided to set the significance value at a $95 \%$ confidence interval level $(\mathrm{p} \leq .05)$ in order to counter the probability of a type I error.

\section{Results}

The distribution of executive remuneration was compared across various categories of industry and job family within the different SOEs.

\section{Descriptive statistics}

Descriptive statistics, which involve the means and standard deviations of the frequency data and percentile distribution of remuneration as per industry, are presented next (see table 1). 
Table 1: Remuneration distribution by industry.

\begin{tabular}{|c|c|c|c|c|c|c|c|c|c|}
\hline \multirow[b]{2}{*}{ Industry } & \multirow[b]{2}{*}{$\mathrm{N}$} & \multirow[b]{2}{*}{ Per } & \multirow[b]{2}{*}{ Min } & \multirow[b]{2}{*}{ Max } & \multirow[b]{2}{*}{ Mean } & \multirow{2}{*}{$\begin{array}{c}\text { Std. } \\
\text { Deviation }\end{array}$} & \multicolumn{3}{|c|}{ PERCENTILE } \\
\hline & & & & & & & 25 & 50 & 75 \\
\hline 1. Transportation/Freight logistics & 20 & 9.0 & 407 & 3318 & 2606.55 & 805.253 & 2538.25 & 2867.00 & 3253.50 \\
\hline 2. Defence & 14 & 6.3 & 706 & 3488 & 1471.79 & 778.675 & 971.75 & 1228.00 & 1616.00 \\
\hline 3. Energy & 27 & 12.2 & 529 & 3107 & 1876.19 & 756.463 & 1232.00 & 1446.00 & 2642.00 \\
\hline 4. Forestry & 12 & 5.4 & 533 & 2265 & 1195.42 & 437.403 & 963.75 & 1182.00 & 1372.50 \\
\hline 5. Telecommunications & 73 & 32.9 & 121 & 3848 & 1399.67 & 821.177 & 911.00 & 1316.00 & 1794.00 \\
\hline 6. Development funding & 40 & 18.0 & 739 & 3557 & 1780.40 & 588.820 & 1385.50 & 1671.50 & 2033.75 \\
\hline 7. Aviation and aerospace & 36 & 16.2 & 697 & 3756 & 1806.89 & 651.390 & 2538.25 & 2867.00 & 3253.50 \\
\hline Total & 222 & & 121 & 3848 & 1694.50 & 802.756 & 971.75 & 1228.00 & 1616.00 \\
\hline
\end{tabular}

The sample shows that on average, entities in transportation have the highest distribution of pay (2606.55), followed by energy (1876.19), aviation and aerospace (1806.89) and development funding (1780.40). The smallest distribution on remuneration occurs in entities in forestry (1195.42) and telecommunication (1399.67). Similarly, with regard to the percentile range, table 1 also indicates that transportation/freight logistics, aviation and aerospace, as well as development funding, are leading in terms of paying executives at the entry, middle and upper quartile in the market, respectively. Defence, forestry and telecommunications were the lowest in terms of the distribution of executive remuneration. 


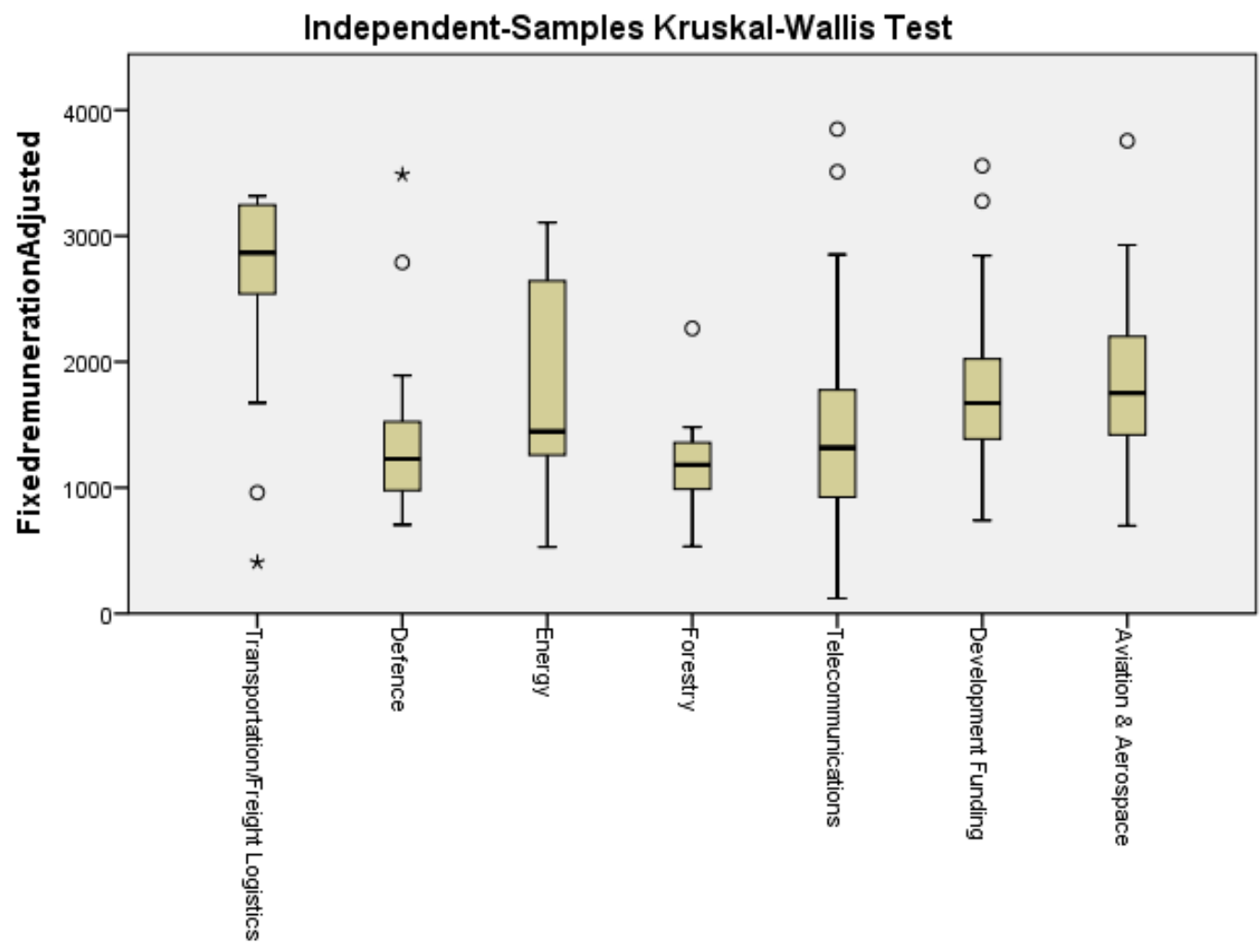

IndustryCode

Figure 1: Graphical presentation of the independent sample by industry.

Graphical presentation of the distribution of remuneration based on various categories of industry indicates that there are few outliers across different industries, except for energy. However, the graph also shows that transportation pays better on average compared to other industries, while the industry that pays least is forestry, together with defence. However, in order to test the null hypothesis and to determine whether there was a significant difference in the distribution of executive remuneration by industry, the Kruskal-Wallis test summary of independent samples was conducted. 


\section{Inferential statistics: Kruskal-Wallis test}

The Kruskal-Wallis test was used by firstly determining the prediction power of the distribution of remuneration as depicted by the model summary of the variables (see table 2).

Table 2: Kruskal-Wallis test summary of distribution of remuneration by industry

\begin{tabular}{lr}
\hline \multicolumn{2}{c}{ Independent-Samples Kruskal-Wallis Test Summary } \\
\hline Total N & 222 \\
Test Statistic & $43.940^{\mathrm{a}}$ \\
Degree Of Freedom & 6 \\
Asymptotic Sig.(2-sided test) & .000 \\
\hline a. The test statistic is adjusted for ties.
\end{tabular}

The summary table indicates that in an analysis of the groups at the $95 \%$ confidence interval they exhibit statistically significant differences $(\mathrm{p}=.000)$. Therefore multiple comparisons were performed because the overall test does show significant differences across samples. The distribution of fixed remuneration across categories of industry is summarised in Table 3 by pairwise comparison. 
Table 3: Pairwise comparison of independent samples by industry

\begin{tabular}{|c|c|c|c|c|c|}
\hline \multicolumn{6}{|c|}{ Pairwise Comparisons of Industry Code } \\
\hline & Test & & Std. Test & & \\
\hline Sample 1-Sample 2 & Statistic & Std. Error & Statistic & Sig. & Adj. Sig. \\
\hline Forestry-Defence & 21.714 & 25.266 & .859 & .390 & 1.000 \\
\hline Forestry-Telecommunications & -22.510 & 20.006 & -1.125 & .261 & 1.000 \\
\hline Forestry-Energy & 59.380 & 22.283 & 2.665 & $.008 *$ & .162 \\
\hline Forestry-Aviation and Aerospace & -60.014 & 21.409 & -2.803 & $.005^{*}$ & .106 \\
\hline Forestry-Development Funding & -60.738 & 21.139 & -2.873 & $.004 *$ & .085 \\
\hline Forestry-Transportation/Freight Logistics & 111.900 & 23.452 & 4.771 & $.000^{*}$ & .000 \\
\hline Defence-Telecommunications & -.796 & 18.739 & -.042 & .966 & 1.000 \\
\hline Defence-Energy & -37.665 & 21.152 & -1.781 & $.075^{* *}$ & 1.000 \\
\hline Defence-Aviation and Aerospace & -38.300 & 20.229 & -1.893 & $.058 *$ & 1.000 \\
\hline Defence-Development Funding & -39.023 & 19.944 & -1.957 & $.050 *$ & 1.000 \\
\hline Defence-Transportation/Freight Logistics & 90.186 & 22.381 & 4.030 & $.000 *$ & .001 \\
\hline Telecommunications-Energy & 36.869 & 14.467 & 2.549 & $.011^{*}$ & .227 \\
\hline Telecommunications-Aviation and Aerospace & -37.504 & 13.080 & -2.867 & $.004 *$ & .087 \\
\hline Telecommunications-Development Funding & -38.227 & 12.635 & -3.026 & $.002 *$ & .052 \\
\hline Telecommunications-Transportation/Freight Logistics & 89.390 & 16.210 & 5.515 & $.000 *$ & .000 \\
\hline Energy- Aviation and Aerospace & -.634 & 16.351 & -.039 & .969 & 1.000 \\
\hline Energy-Development Funding & -1.358 & 15.997 & -.085 & .932 & 1.000 \\
\hline Energy-1 Transportation/Freight Logistics & 52.520 & 18.948 & 2.772 & $.006 *$ & .117 \\
\hline Aviation and Aerospace-Development Funding & .724 & 14.755 & .049 & .961 & 1.000 \\
\hline Aviation and Aerospace-Transportation/Freight Logistics & 51.886 & 17.912 & 2.897 & $.004 *$ & .079 \\
\hline Development Funding- Transportation/Freight Logistics & 51.163 & 17.589 & 2.909 & $.004 *$ & .076 \\
\hline
\end{tabular}

Each row tests the null hypothesis that the Sample 1 and Sample 2 distributions are the same.

Asymptotic significances (2-sided tests) are displayed. The significance level is .05.

*Significance level: $p<.05$ level.

**Significance level: $p<.10$ level.

Table 3 indicates that the distributions of fixed remuneration were significantly different across categories of industry, using the Kruskal-Wallis test: $X^{2}(6)=43.940, p<0.00$. Pairwise comparisons using the Kruskal-Wallis test $(\mathrm{p}=.05)$ revealed that the distribution of remuneration was the same for all categories of industry except between forestry - defence (.859), forestry - telecommunication $(-1.125)$, defence - telecommunications $(-.042)$, energy - aviation (-.039), energy - development funding (-.085) and aviation - development funding 
(.049). It could therefore be concluded that the distribution of executive remuneration is not the same across various categories of industry in South African SOEs. The null hypothesis is thus rejected.

\section{Remuneration distribution of the independent sample by job family}

Descriptive statistics and the means and standard deviations of the frequency data according to the distribution of remuneration by job family are presented next.

Table 4: Remuneration distribution by job family

\begin{tabular}{lrrrrr}
\hline Job family & $\mathrm{N}$ & \multicolumn{1}{c}{ Mean } & Std. Dev & Min & Max \\
\hline 1. Strategy & 13 & 2049.31 & 753.217 & 1238 & 3848 \\
2. Administration & 57 & 1823.40 & 993.941 & 121 & 3756 \\
3. Operations & 47 & 1574.87 & 538.536 & 652 & 2666 \\
4. Human Resources & 27 & 1631.15 & 737.393 & 123 & 3309 \\
5. Finance & 22 & 1719.55 & 883.660 & 146 & 3557 \\
6. Information technology & 8 & 2053.88 & 809.060 & 1224 & 3488 \\
7. Legal and risk & 22 & 1261.41 & 614.684 & 123 & 2629 \\
8. Sales and marketing & 13 & 1799.00 & 728.474 & 1049 & 3060 \\
9. Research and development & 1 & 1085.00 & & 1085 & 1085 \\
11. Strategy and admin & 5 & 1310.20 & 697.837 & 706 & 2399 \\
12. Strategy and finance & 6 & 2192.67 & 914.275 & 1338 & 3510 \\
Total & 221 & 1696.05 & 804.246 & 121 & 3848 \\
\hline
\end{tabular}

The independent samples of various categories of job family in table 4 show that the distribution of remuneration on average was high in strategy and finance (2192.67), information technology (2053.88) and strategy (2049.31), followed by administration (1823.40), sales and marketing (1799.00) and finance (1719.55), respectively. The least distribution of remuneration by job family was found in human resources (1631.15), operations (1574.87), strategy and administration (1310.20), legal and risk (1261.41), and research and development (1085.00), respectively. 
However, in order to test the null hypothesis and to determine whether there was a significant difference in the distribution of executive remuneration according to job family, the KruskalWallis test summary of independent samples was conducted.

Table 5: Kruskal-Wallis test summary of Distribution of remuneration by job family

\begin{tabular}{lr}
\hline \multicolumn{2}{c}{ Independent-Samples Kruskal-Wallis Test Summary } \\
\hline Total N & 221 \\
Test Statistic & $17.193^{\mathrm{a}, \mathrm{b}}$ \\
Degree Of Freedom & 10 \\
Asymptotic Sig.(2-sided test) & .070 \\
\hline
\end{tabular}

a. The test statistic is adjusted for ties.

b. Multiple comparisons are not performed because the overall test does not show significant differences across samples.

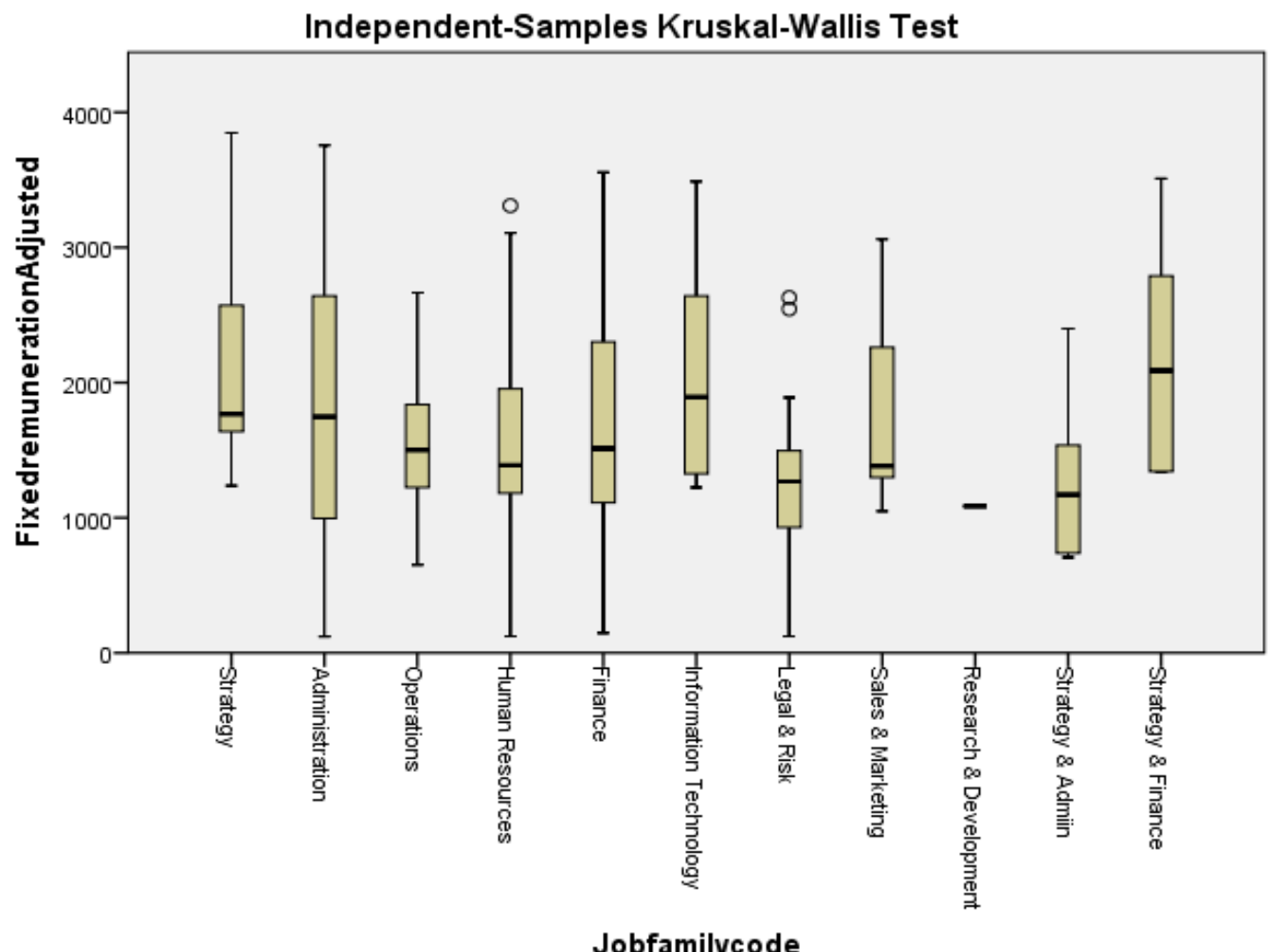

Figure 2: Graphical presentation of remuneration by job family 
According to the hypothesis test summary using independent samples to conduct the KruskalWallis test, the variables in each model fell above the accepted level of significance $(\mathrm{p}<=0.05)$ and consequently, multiple comparisons were not performed because the overall test at $(\mathrm{p}<=$ 0.07) did not show significant differences across samples. It can thus, statistically and significantly, be concluded that the distribution of remuneration is the same across various categories of job family in all South African SOEs under study. The null hypothesis is therefore accepted.

\section{Discussion and conclusion}

An investigation into the distribution of executive remuneration based on various categories of industry and job family provides insight into the research and practice in establishing executive remuneration in South African SOEs. The result, based on the initial percentile distribution of remuneration according to various categories of industry, seems to suggest on the one hand that industries including transportation/freight logistics, aviation and aerospace and development funding were leading in terms of the distribution of executive remuneration at the entry, middle and upper quartile in the market. On the other hand, the distribution of executive remuneration was lowest in defence, forestry and telecommunications. The distribution of remuneration based on the percentile rank seems to imply that it would be ideal for an executive who aims at a high package relative to industry to work for a South African SOE in the transportation/freight industry rather in telecommunication. Similarly, it would seem ideal for such an executive to work for an institution in aviation and aerospace rather than one in defence. However, the statistics were only based on independent treatment of the sample.

The actual testing and analysis of the null hypothesis, using pairwise comparison, revealed that the distribution of remuneration was not the same in all categories of industry, except between forestry - defence, forestry - telecommunication, defence - telecommunication, energy - 
aviation, energy - development funding, and aviation - development funding. The results seem to imply that executives who moved from the aforementioned paired industries would expect a change in their executive package, which could be either positive or negative in terms of salary.

However, the results also indicated that there was no difference in the distribution of remuneration across various categories of job family in South African SOEs. It would appear that job family does not have an effect on the distribution of executive remuneration in the different SOEs. Thus, the finding is that it would be a challenge to use similar or comparable jobs within the same job family as differentiators in determining executive remuneration.

The findings of the research make an important contribution to the determinants of executive remuneration and extend the scope of the theory and empirical research by showing the strong predictive value of the one variable, namely the type of industry, on executive remuneration as being more informative compared to job family. Findings of the research seem consistent with previous literature (Trevor, 2010, Ghose, 2011) and the contingency theory, which both contend that the type of industry is the main determinant of executive remuneration. In addition, findings in this study are consistent with previous studies (Ang, Nagel \& Yang, 2013; Bizjak, Lemmon, \& Nguyen, 2011; Bizjak, Lemmon, \& Naveen, 2008; Faulkender \& Yang, 2010) that support industry as the benchmark for executive remuneration and also assert that executive pay is benchmarked against industry peers of comparable size to justify CEO pay.

These findings are welcome for researchers, as they provide empirical justification for using, combining and comparing variables as determinants of executive remuneration as researched in this study. Industry, as a pay benchmarking criterion in executive remuneration and as investigated in this study, may have significant implications for remuneration philosophy that guides the setting and implementation of executive remuneration in the context of SOEs. The 
empirical data about the relevance of the type of industry within SOEs prove that executive remuneration in SOEs cannot be appropriately determined without understanding the implication of the type of industry to which an enterprise belongs. However, further research is needed to investigate what makes the various categories of industry different, warranting the difference in pay, since they are all SOEs.

Because of the lack of a proper guide to executive remuneration, some South African SOEs are challenged to the extent that maladministration and corruption taint the manner in which executive remuneration is determined and managed. From a public policy research perspective it would be rewarding to assess, besides the type of industry as a criterion for determining executive remuneration, the law creation processes and to explore why the remuneration guidelines for SOEs seem remote from those that govern the private sector (Papenfuß \& Schmidt, 2015).

In an international comparative perspective, the discussion about principles of good and responsible public corporate governance, scholars and practitioners have suggested and reinforced the need for transparent disclosure of top-management compensation (OECD 2005; Papenfuß \& Schmidt, 2015; Whincop 2005, p. 227). Although the Organisation for Economic Co-operation and Development (OECD) governance codes seem to serve only as a reference point for many countries developing their own national corporate governance codes, the OECD is nevertheless an important point of departure when determining executive remuneration.

However, a move towards harmonisation of the legal status of SOEs with companies in the private sector is beginning to take place, which in turn could facilitate a more systematic use of corporate governance instruments (PwC, 2015). For instance, the International Public Sector Accounting Standards Board is in the process of clarifying how companies that are owned by 
the government should be defined. This will determine which financial reporting standards apply (PwC, 2015).

With regard to future research gaining comparative empirical insights about more countries, especially in terms of how industry as a benchmark for determining executive remuneration is treated, would be of particular interest. Most research on SOEs seems to be done in western developed countries. In comparison, there is still lack of empirical research on SOEs in developing countries such as South Africa. Strengthening comparative approaches in this field seems especially valuable as a means of gathering new insights to improve the management of public service institutions such as SOEs. However, whether the type of industry as a criterion in benchmarking executive remuneration can be applied in practice in the same way in all countries remains to be seen.

Likewise, the result for job family revealed that the distribution of executive remuneration across various categories of job family was non-significant as a determinant of executive remuneration across all individual SOEs and further research on the causes would thus be invaluable. 


\section{References}

African National Congress Policy discussion paper on SOEs and DFIs (2012). Economic transformation. Jan. Retrieved from: http://www.anc.org.za/docs/discus/2012/economym.pdf Ang, J., Nagel, G., Yang, J. (2013). The effect of social pressures on CEO compensation. Working paper. Florida State University.

Bizjak, J. M., Lemmon, M. L., \& Naveen, L. (2008). Does the use of peer groups contribute to higher pay and less efficient compensation? Journal of Financial Economics, 90(2), 152-168. Bizjak, J., Lemmon, M., \& Nguyen, T. (2011). Are all CEOs above average? An empirical analysis of compensation peer groups and pay design. Journal of Financial Economics, 100(3), $538-555$.

Bouwman, C. (2013). The geography of executive compensation, Working paper, Case Western University.

Bozeman, B. (1987). All Organizations Are Public: Bridging public and private organizational theories. San Francisco: Jossey-Bass.

Bullock, J. B., Stritch, J. M., \& Rainey, H. G. (2015). International comparison of public and private employees' work motives, attitudes, and perceived rewards. Public Administration Review, 75(3), 479-489.

Chatterji, M., Mumford, K., \& Smith, P. N. (2011). The public-private sector gender wage differential in Britain: Evidence from matched employee-workplace data. Applied Economics, 43(26), 3819-3833.

Conyon, M. J., \& He, L. (2011). Executive compensation and corporate governance in China, Journal of Corporate Finance, 17(4), 1158-1175.

Crotty, A., \& Bonorchis, R. (2006). Executive Pay in South Africa: Who gets what and why? Cape Town: Juta and Company Ltd. 
Datta, S., \& Iskandar-Datta, M. (2014). Upper-echelon executive human capital and compensation: Generalist vs specialist skills. Strategic Management Journal, 35: 1853-1866. doi: $10.1002 / \mathrm{smj} .2267$

Faulkender, M., \& Yang, J. (2010). Inside the black box: The role and composition of compensation peer groups. Journal of Financial Economics, 96(2), 257-270.

Fernandes, N. G., Miguel A. F, Pedro, P. M, and Kevin J. M. (2012). Are US CEOs paid more? New international evidence. EFA 2009 Bergen Meetings Paper; AFA 2011 Denver Meetings Paper; ECGI - Finance Working Paper No. 255/2009. http://ssrn.com/abstract=1341639. Fin24.com (2009). Money rolled in for Maroga. 24 November. Retrieved from http://www.fin24.com/Business/Money-rolled-in-for-Maroga-20091124.

Ghose, A. (2011), Total rewards special: Decoding executive compensation. Compensation Benefits. 15 March", AonHewitt.

http://www.peoplematters.in/article/2011/03/15/compensation-benefits/total-rewards-specialdecoding-executive compensation/882< accessed on 31 October 2014.

Greckhamer, T. (2011). Cross-cultural differences in compensation level and inequality across occupations: A set-theoretic analysis. Organization Studies, 32(1), 85-115.

Gomez-Mejia, L. R., Berrone, P., \& Franco-Santos, M. (2010). Compensation and Organizational Performance: Theory, research, and practice. New York: ME Sharpe Inc.

Greve, A., Benassi, M., \& Sti, A. D. (2010). Exploring the contributions of human and social capital to productivity. International Review of Sociology-Revue Internationale de Sociologie, 20(1), 35-58.

Hattingh, D., Hodge, J., \& Rospabe, S. (2003). The Impact of Privatisation and Regulatory Reform on Wage Premia in State-Owned Enterprises in South Africa. Development Policy Research Unit, University of Cape Town. 
Hijazi, S. T., \& Bhatti, K. K. (2007). Determinants of executive compensation and its impact on organizational performance. Compensation \& Benefits Review, 39(2), 58-68.

Houston, D. J. (2011). Implications of Occupational Locus and Focus for Public Service Motivation: Attitudes toward work motives across nations. Public Administration Review 71(5): 761-71.

Khanna P., Jones C.D., Boivie S. (2014). Director human capital, information processing demands, and board effectiveness. Journal of Management 40(2): 557-585.

Kjeldsen, A. M., \& LotteBøgh A. (2013). How Pro-social motivation affects job satisfaction: An international analysis of countries with different welfare state regimes. Scandinavian Political Studies 36(2): 153-76.

Li, Q. (2015). The discussion of theory review and practice on enterprise executives incentive. Journal of Human Resource and Sustainability Studies, 3(01), 51.

Lorsch, J. \& Khurana, R. (2010), The pay problem. Time for a new paradigm for executive compensation, Harvard Magazine, May/June, 30 - 35.

Maloa, F. \& Rajah, M. (2012). Determinants of employee compensation: An exploratory study. South African Journal of Labour Relations, 36 No 2.

Martocchio, J. J. (2011). Strategic Compensation. Upper Saddle River, NJ: Prentice Hall. Musolf, L. D., \& Seidman, H. (1980). The blurred boundaries of public administration. Public Administration Review, 40 (2), 124-130.

Ng, T. W., \& Feldman, D. C. (2010). Human capital and objective indicators of career success: The mediating effects of cognitive ability and conscientiousness, Journal of Occupational and Organizational Psychology, 83(1), 207-235.

Oberholzer, M., \& Theunissen, M. (2012). Benchmarking of Johannesburg Stock Exchange CEO compensation. International Business \& Economics Research Journal (IBER), 11(9), 1061-1076. 
OECD (2005): OECD Guidelines on Corporate Governance of State-Owned Enterprises, OECD-Publishing.

OECD (2011): The Size and Composition of the SOE Sector in OECD Countries, OECD Working Paper No. 5, www.oecd.org/daf/corporateaffairs/wp,

O’Toole, L. J., \& Meier, K. J. (2015). Public management, context, and performance: In quest of a more general theory. Journal of Public Administration Research and Theory 25(1): 23756.

Papenfuß, U., \& Schmidt, C. (2015). Determinants of manager pay in German state-owned enterprises and international public policy implications: 3-year study for sectors, performance and gender. Working paper. Universität Leipzig.

Perkins, S.J \& White, G. (2011). Employee Reward: Alternatives, consequences and contexts. $2^{\text {nd }}$ edition. London: Chartered Institute of Personnel and Development.

Presidential review committee on State Owned Entities. (2013) Volume 1. Executive summary of the final report. Retrieved October 2014, 20, from http://www.thepresidency.gov.za/electronicreport/downloads/volume_1/volume_1.pdf PwC (PricewaterhouseCoopers). (2010). Executive remuneration in need of a major makeover. PwC: 1-3, 23 Jul. Retrieved from: http://www.pwc.com/za/en/press-room/ PwC (PricewaterhouseCoopers). (2015). State owned enterprises. Catalysts for public value creation. PwC: April: Retrieved from: http://www.psrc.pwc.com.

Ramlall, S., Maimani, K. \& Diab, A. (2011). Compensation practices and plan effectiveness in Saudi Arabia. Compensation Benefits Review. January/February, 43(1), 52-60.

Risher, H. (2012), How well are government employees paid? Compensation and Benefits Review,(44)2, 73-79. 
Rodriguez, P., Uhlenbruck, K., \& Eden, L. (2005). Government corruption and the entry strategies of multinationals. Academy of Management Review, 30(2), 383-396.

Sarkar, J. (2013). Investigation into the relationship between executive compensation and firm performance. Available at SSRN 2403184

Saunders, M. N., Saunders, M., Lewis, P \& Thornhill, A. (2011), Research Methods for Business Students, $\left(5^{\text {th }}\right.$ edn) Harlow, England: Financial Times, Prentice Hall.

Scholtz, H. E., \& Smit, A. (2013), Executive remuneration and company performance for South African companies listed on the Alternative Exchange (AltX), Southern African Business Review, 16(1), 22-38.

Sowetan (2012). State challenged on directors' pay freeze. 25 April. Retrieved from http://www.sowetanlive.co.za/news/2012/04/25/state-challenged-on -directors-pay-freeze.

Sowetan (2012). Gigaba plans to curb executive pay. 14 March. Retrieved from: http://www.sowetanlive.co.za/news/business-news/2012/03/14/gigaba-plans-to-curbexecutive-pay.

Sowetan (2012). It's just too much for Gigaba. 16 March. Retrieved from: http://www.sowetanlive.co.za/columnists/2012/03/16/it-s-just-too-much-for-gigaba.

Sun, S. L., Zhao, X., \& Yang, H. (2010), Executive compensation in Asia: A critical review and outlook. Asia Pacific Journal of Management, 27(4), 775-802.

Tijdens, K. G., \& Van Klaveren, M. (2012). Frozen in time: Gender pay gap unchanged for 10 years. Brussels, ITUC.

Theunissen, P. (2010). Is Executive Remuneration out of Control? Bethlehem: Computus. Transparency International Corruption Perception Index. (2014, 2013, 2011, 2010, 2009, 2008, 2007, 2005, 2002) Retrieved from http://www.transparency.org/cpi2014 Trevor, J. (2011), Can Pay be Strategic? A critical exploration of strategic pay in practice. United Kingdom: Palgrave Macmillan. 
Van Essen, M., Otten, J., \& Carberry, E. J. (2012). Assessing managerial power theory: A meta-analytic approach to understanding the determinants of CEO compensation. Journal of Management, 0149206311429378. 